\title{
SUSTAINED YIELD THROUGH LEGISLATION ${ }^{1}$
}

\author{
by J. F. SHARPE \\ Ontario Forest Service, Toronto, Ontario
}

I feel that to give a paper on the subject of sustained yield is somewhat analagous to the words in the negro spiritual song "Heav'n"- "Ev'rybody talkin' bout Heav'n ain't going there."

Sustained yield forest management has been much talked and written about-yet not too much has been done about it.

The text books tell us that sustained yield is the yield or cut of timber from a forest which is managed in such a way that annually or periodically the quantity of timber removed equals the increment.

There is nothing mysterious in this definition nor can there be any doubt about the advantages accruing both to the owners of the forest and to the users of the forest from such practices. It is under this kind of management that industry is sustained-every business aims at continuous production. Therefore, it should not be peculiar in a forest business any more than in any other business enterprise. A natural question is--why, then, are there so few examples to point to where sustained yield management is practised.

Until a comparatively few years ago industry, particularly the lumber industry, perhaps felt that it was carrying on operations on a continuous basis-when one area was cut off there was always another waiting. This does not apply today, as evidence the gradual decline in the annual cut of white and red pine in Ontario. Forty years ago we cut annually in this province five to six times what we produce today. In another $20-30$ years we shall see the end of the virgin pine stands. I do not infer it was or is wrong to cut the accumulated increment as that would seem the proper thing to do. However, I do believe that it will be after the mature stands have been cut that we will have the best opportunity to gear production to growth. This process is now taking place in Southern Ontario and it is of interest to note that we have completed plans to place 1,000 square miles under management within the area of the Petawawa river watershed. This tract will support an annual cut of $31 / 2$ million cubic feet of white and red pine along with $71 / 2$ million cubic feet of other species. The established industries in and about Pembroke will get the first chance to secure this volume.

At the present time in Ontario there are many sawmills that cannot be supplied on any continuous basis from the areas now held or which can be made available to supply their raw material. Were production reduced below what is necessary for economic operation many mills would have to close now rather than in a few years when the mature timber is cut.

The Division of Timber Management of the Lands and Forests Department is now encountering this very situation. We have required industry to take inventory and prepare management plans. We are now receiving these plans and we discover on analysis that several areas held under licence will only support a cut of $1 / 3$ of the raw material required to operate the plant at its rated capacity.

1. Presented at the 41st annual meeting of the Canadian Society of Forest Engineers, Toronto, October $24-26,1949$ 


\section{SUSTAINED YIELD-SHARPE}

To reduce capacity to the dictates of good forest management is in many cases tantamount to putting the operator out of business. What we have to face is the fact the processing plant rather than the forest has always dictated the kind of timber which will be utilized and that its capacity has decided the volume of raw material it must have annually in order that operations may be carried on profitably.

Under this arrangement it is not possible to practise sustained yield management. In my own opinion, and to repeat, there is little that can be done until after the mature forest has been cut, or in other words, until the second rotation is entered. When the mature timber has been removed there will be cases where there is no choice but for the industry to cease operations, insofar as the areas immediately available are concerned. It will be then and then only that there will be an opportunity to manage according to the annual or periodic incrernent, and even then only so long as fire or insects do not defeat the scheme a second time.

This trend, not uncommon in the past, will not be uncommon in the future. There have been ghost settlements and there will be others. However, such settlements should become less and less frequent.

What has been said applies more to timber held under the license system. While we still offer timber for sale by public competition, legislation enables us to set aside areas by agreement for the benefit not only of established industries but for new industries. Therefore, these comments need not necessarily apply to unalienated Crown lands or to forest holdings now believed sufficient in size to support dependent industry continuously.

A few statistics will illustrate:

Total forest area

Held under Concession Agreement and believed

Licensed sufficient to support the dependent industry

Unalienated

$110,000,000$ acres

$$
\begin{array}{r}
44,000,000 \text { acres } \\
8,000,000 \text { acres } \\
58,000,000 \text { acres }
\end{array}
$$

Industries dependent on the licensed areas are in a more unstable condition on account of their relatively small individual holdings. The maintenance of future production on these areas depends to a large extent on the integration of operations on agreement areas and on the management of the unalienated lands. Such industry is a small percentage of the total and need not affect efforts to promote forest management over the bulk of our forested lands.

It is our considered opinion that Ontario has now embarked on a program which will lead to a proper regulation of the cut. However, many problems confront us and one of the most serious is how to economically control the character of the second crop.

You will note that my statements are not too definite. It was with some hesitancy that I agreed to prepare a paper on this subject because I still believe that the methods by which we shall proceed in the future are somewhat speculative.

On the other hand I have no reason to doubt the wisdom of our present 
attempt to regulate the cut from the Crown Lands in Ontario, and I would like to briefly summarize some of those activities under the headings

Legislation

Forest Inventory

Field Organization

Subdivision of the Forest Area into Management Units.

\section{Legislation}

Several Acts authorize action on the part of lessees and licensees of Crown timber but the most important Act is "The Forest Management Act" passed in 1947. Clauses from this Act are quoted below:

"Every person who has cutting rights in a Crown timber area shall, when required by the Minister, furnish to him-

(a) An estimated inventory of the timber on the Crown timber area witli respect to which he has cutting rights, classifying the timber as to age, species, size and type;

(b) A master plan for managing the Crown timber area and utilizing the timber thereon; and

(c) A map, which shall form a part of the master plan, dividing the Crown timber area into proposed operational units.

Section 2, Subsection (2)

The Minister may approve a master plan as submitted to him or may approve it with such alterations therein as he may deem advisable.

Section 2, Subsection (3)

Subject to section 3 , a person who has received a request to furnish a master plan shall manage the Crown timber area covered by it and utilize the timber thereon in accordance with the provisions of the approved master plan."

Under the Forest Management Act industry has already been directed to comply with the terms involved in the area previously referred to, i.e., the $44,000,000$ acres held under concession agreement.

\section{FOREST INVENTORY}

Considerable publicity has been given to our program for completing a forest resources inventory for Ontario.

The present position is as follows:

Total area to be covered $110,000,000$ acres. As at October 1st, 1949, our progress since April, 1946, can be summarized as follows:

Area photographed

Planimetric maps prepared on a scale of 20 chains $=1$ inch

Field work completed for $94,600,000$ acres

Timber type maps prepared for

Timber estimated on

$66,800,000 "$

$23,000,000$

$11,800,000 "$

Timber type maps are being prepared for the entire area photographed. All companies or individuals holding cutting rights on areas in excess of 30,000 acres are required to submit forest type maps for approval, also an 
inventory of timber and plan of utilization. These activities are keeping pace with those of the Department, and the whole is scheduled for completion by March 31st, 1953.

\section{Field Organization}

As the inventory is completed a District Division of Timber Management is organized in each district. The Districts of Algonquin, North Bay, Sudbury, Temiskaming, Cochrane, Geraldton and Port Arthur have been so organized. The District Management Forester has been trained under the Forest Resources Inventory program. These same men have prepared the forest type maps and have supervised the field work for the district to which they are now attached.

To complete the district organization more assistant foresters will be required as will a staff of trained rangers.

The Department of Lands and Forests now employs 120 foresters, 40 of whom are in Timber Management work. We hope to increase the number in management to 60 in the next two years.

\section{Subdivision of the Forest ARea into Management Units}

The third step in the plan is the division of the forest area of Ontario into management units. Generally speaking management units will be confined within a single drainage area or a group of drainage areas. Through utilization surveys we know the requirements of established industry. The volumes required will be related to the cutting budget, decided for the unit from the inventory data.

This in a general way outlines the efforts of the Ontario Department of Lands and Forests to attain a regulation of the cut from Crown Lands.

Before concluding I should like to make a few additional observations.

In Ontario, foresters have had only fifteen years in which to register achievement and most of these have been depression and war years.

After the Provincial Government decided to employ technical foresters in 1921-22, the province was sub-divided into districts and the foresters were given the task of organizing a forest fire protection system. A general forest reconnaissaince of the forest area of the province was also undertaken. UP to 1935 two separate field organizations were maintained, one responsible for protection, the other for measuring the volume of timber cut from Crown lands. These two bodies were subsequently amalgamated and foresters then had the opportunity to deal with timber administration. A technical forester became head of our Department in 1941 for the first time.

Now a word on the geography of the province-only $1 / 3$ of the forest area drains to the Great Lakes and St. Lawrence systems or towards the market. Two-thirds drains directly to James Bay or indirectly through Manitoba to Hudson Bay or away from the market.

The railway and highway system apart from any mileage built by industry in Northern Ontario is about one mile of road to 40 square miles of forest area. 
Ontario's population is distributed so that 90 per cent is on 10 per cent of the provincial area and 10 per cent on 90 per cent of the area.

The representatives to the provincial legislature are elected much according to the same ratio.

These facts all influence the progress of forestry in the Province of Ontario.

We believe that forest management must be accomplished by industry. Here let me quote from a paper prepared by J. H. White in 1929:

"The simplest first step in forest management will mean expenditure of money, just as truly in regulated logging as in planting. In no business can we increase production returns without investing money. One of our myths is that in some mysterious way we can travel along some easier trail, or find some short cut to the managed forest goal. We may as well give up such expectation-Nature will always grow her forests in the same old way.

"There is another myth which is helping to delay a commencement, and that is, that the operator cannot make any change in his methods unless he sees a direct return. If that view is to stand, the case is hopeless-we shall never start. Expenditure is unescapable. The operator must be the medium through which the outlay is made, but what he cannot pass on to the consumer of forest products, what he cannot carry in competition with outside operators, must be met by the state." 